\title{
Shifting individual habitat specialization of a successful predator living in anthropogenic landscapes
}

\author{
Joan Navarro ${ }^{1,2, *}$, David Grémillet ${ }^{2}$, Francisco J. Ramirez ${ }^{1}$, Isabel Afán ${ }^{1}$, \\ Willem Bouten ${ }^{3}$, Manuela G. Forero ${ }^{1}$ \\ ${ }^{1}$ Estación Biológica de Doñana CSIC, Avda. Américo Vespucio s/n, Sevilla 41092, Spain \\ ${ }^{2}$ Centre d'Ecologie Fonctionnelle et Evolutive, UMR 5175, \\ CNRS - Université de Montpellier - Université Paul-Valéry Montpellier - EPHE, 34293 Montpellier, France \\ ${ }^{3}$ Computational Geo-Ecology, Institute for Biodiversity and Ecosystem Dynamics IBED, University of Amsterdam, \\ PO Box 94248, 1090 GE Amsterdam, The Netherlands
}

\begin{abstract}
Population expansions of successful species have gained importance as a major conservation and management concern. The success of these 'winners' is widely attributed to their high adaptability and behavioural plasticity, which allow them to efficiently use opportunities provided by human-modified habitats. However, most of these studies consider conspecifics as ecological equivalents, without considering the individual components within populations. This is critical for a better understanding of the main ecological mechanisms related to the success of winning species. Here, we investigated the spatial ecology of the opportunistic yellow-legged gull Larus michahellis, a clear example of a winning species in southern Europe, to examine its degree of individual specialization in habitat use. To test for such individual strategies, we applied specialization metrics to spatial data obtained from 18 yellow-legged gulls that were GPS-tracked simultaneously during the breeding season. The results revealed that population-level generalism in habitat use in the yellow-legged gull arises through varying levels of individual specialization, and individual spatial segregation within each habitat. Importantly, we found that the combination of individual specialization and individual spatial segregation may reduce intra-specific competition, with these 2 important mechanisms driving the success of this winning species.
\end{abstract}

KEY WORDS: Foraging strategies · Gulls $\cdot$ GPS $\cdot$ Habitat use $\cdot$ Individual specialization $\cdot$ Movement ecology $\cdot$ Opportunistic seabirds $\cdot$ Seabird $\cdot$ Spatial ecology $\cdot$ Winning species

\section{INTRODUCTION}

Human activities are globally impacting ecosystems, with important effects on biodiversity, including extinction processes (McKinney 2006, Worm et al. 2006). Species vary in their responses to human perturbations; while most seem unable to cope with drastic changes, others may persist, or even flourish within human-transformed ecosystems (McKinney \& Lockwood 1999). The general pattern of expansion of some widespread non-native and native species, so-

${ }^{*}$ Corresponding author: joan@ebd.csic.es

${ }^{\S}$ Advance View was available online May 15, 2017 called 'winners', and the contraction of rare and often endemic native species, so-called 'losers', leads to a biotic homogenization process. This has led to biological impoverishment worldwide (Olden et al. 2004).

Population expansions of winning species have gained importance as a major conservation and management concern (Cardador et al. 2011, Sih et al. 2011, Newsome et al. 2015). The success of these winners is widely attributed to their high adaptability and behavioural plasticity, which allow them to efficiently exploit opportunities provided by novel, 
human-modified environments (Shultz et al. 2005, Clavel et al. 2011). Among marine predators, it is well-known that some gull species are particularly successful. They efficiently adapt to exploiting a wide suite of novel resources that provide direct biotic and abiotic benefits, including food, shelter and refuge from predation (Ramírez et al. 2012, Alonso et al. 2015, Osterback et al. 2015). These winning seabirds are often perceived as pests because of their impacts on urban areas, water reservoirs and threatened species (Vidal et al. 1998, Skórka et al. 2014, Rock et al. 2016). As a consequence, abundant research has been conducted on these opportunistic predators, mainly focused on their population dynamics, feeding ecology, pollution levels and pathogen load (e.g. Ramos et al. 2011, Payo-Payo et al. 2015). However, most of these studies consider conspecifics as ecological equivalents. Although this simplification can be useful to provide an overview of population-level feeding preferences or population dynamics (Ramos et al. 2011, Payo-Payo et al. 2015), taking into account the individual component within populations is essential for a better understanding of the main ecological mechanisms related to the success of winning species (Grémillet et al. 1999, Cardador et al. 2012, Chapple et al. 2012, Liebl \& Martin 2014, Ceia \& Ramos 2015, Potier et al. 2015)

Individual specialization occurs when some individuals within a population utilize only a subset of the resources that the population uses as a whole. This may be expressed via an animal's diet, patterns of movement or other specific behaviour (Bolnick et al. 2003, Matich et al. 2011, Ceia \& Ramos 2015). Individual specialization may vary between populations and across species, which may further enhance ecological consequences at the individual level (Bolnick et al. 2003, Araújo et al. 2011). Variation in individual specialization directly affects the population dynamics of winning species, by facilitating their adaptability to a large suite of environmental conditions, while reducing competition among conspecifics (Bolnick et al. 2003, Tinker et al. 2007, Dall et al. 2012, Liebl \& Martin 2014). Thus, taking into account the individual component should allow for a better understanding of ecological processes. In addition, knowing the degree of individual specialization in winning species that negatively affect human or wildlife health may help to implement more effective management actions (Sanz-Aguilar et al. 2009, Bowen \& Lidgard 2013, Ceia et al. 2014).

In the present study, we investigated the spatial ecology of the opportunistic yellow-legged gull Larus michahellis in a breeding population of southeastern
Spain, to examine its degree of individual specialization in habitat use. This species is a clear example of a winning predator in southern Europe, as a result of its ability to efficiently exploit a diverse suite of novel resources (e.g. Alonso et al. 2015, Payo-Payo et al. 2015, Martínez-Abraín \& Jiménez 2016). This gull is also considered a pest within urban, agricultural and coastal areas (Vidal et al. 1998). Based on previous information (Ceia et al. 2014, Tyson et al. 2015, Ceia \& Ramos 2015), we hypothesized that yellow-legged gulls present a significant level of individual differences in habitat use. Specifically, we predicted that individuals within the population would show niche segregation with respect to habitat use. To test for such individual strategies, we applied metrics previously used to identify diet specialization (Bolnick et al. 2002, Fodrie et al. 2015). These metrics were applied to spatial data obtained from 18 yellowlegged gulls that were GPS-tracked simultaneously during $4 \mathrm{wk}$ of the breeding season (Bouten et al. 2013). This is one of the first studies to investigate the spatial movements of this gull species continuously across several weeks (see Ceia et al. 2014).

\section{MATERIALS AND METHODS}

\section{Fieldwork procedures}

Fieldwork was carried out at the natural protected Biosphere Reserve of Marismas del Odiel (37 $13^{\prime} \mathrm{N}$, $6^{\circ} 59^{\prime}$ W, Gulf of Cadiz, SW Iberian Peninsula; Fig. 1) in a colony of 250 to 300 breeding pairs. To investigate spatial movements during the breeding period (May 2015), we deployed high-resolution GPStrackers recording the positions of individuals at 5 min intervals (www.UvA-BiTS.nl; Bouten et al. 2013) on 18 breeding adult gulls $>4$ yr old. Age was determined from plumage characteristics. Incubating birds were caught at the nest using a walk-in wire mesh trap and devices were attached using a wing harness fixed with a reef knot in the tracheal pit, an attachment method recommended for large gulls (see Thaxter et al. 2014, 2016). The GPS logger and harness weighed less than $1.8 \%$ of the body mass of the birds (19 $\mathrm{g}$ for the GPS versus $1062 \pm 120 \mathrm{~g}$ [mean \pm $\mathrm{SD}$ ] for the tracked gulls), less than the 3 to $5 \%$ threshold suggested for seabirds (Phillips et al. 2003, Passos et al. 2010). GPS data were downloaded remotely through a local base station and automatically uploaded to the central database (Bouten et al. 2013). To avoid potential biases associated with differences between individuals in the number of days with GPS 

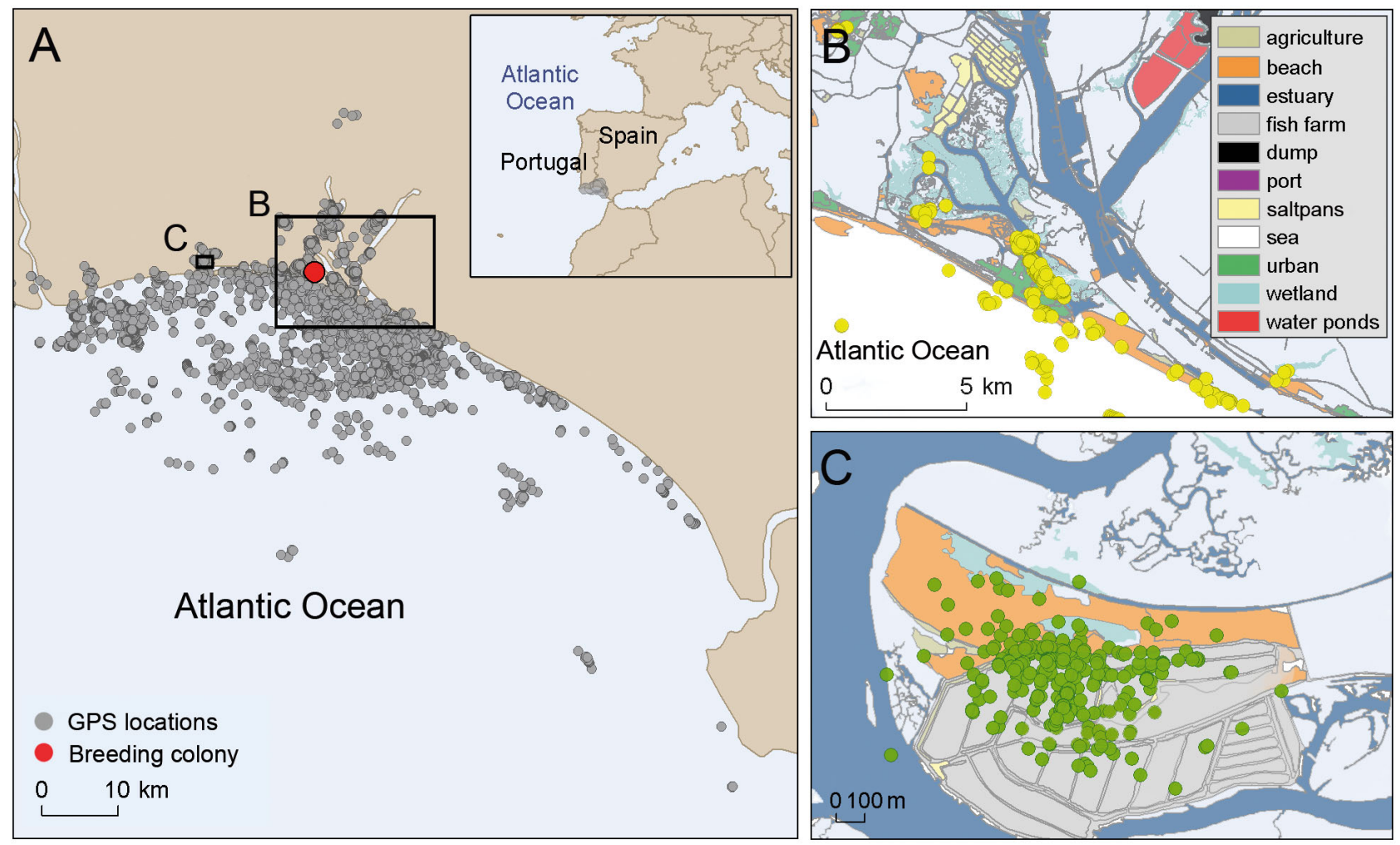

Fig. 1. (A) Study area showing the filtered GPS locations of the 18 tracked yellow-legged gulls Larus michahellis during the 2015 breeding season; (B) example of the habitats exploited by a generalist individual; and (C) example of an individual that specializes in the use of fish farm habitats

data and the potential differential spatial behaviour during the breeding period, we focused our analyses on the time period from 14 May to 15 June 2015 (incubation period). We considered only locations recorded outside the colony (using a radius of $500 \mathrm{~m}$ around each nest) and we removed all travelling locations (speed $>4 \mathrm{~km} \mathrm{~h}^{-1}$; Navarro et al. 2016). The total number of GPS locations ranged from a mean of 8200 to 9129, with a mean of $8644 \pm 495$ locations ind. ${ }^{-1}$.

\section{Individual specialization and individual spatial segregation}

Individual specialization in habitat use by each tracked yellow-legged gull was quantified following Bolnick et al. (2002) and Fodrie et al. (2015). Specifically, we calculated the proportional habitat use by each yellow-legged gull as the number of habitatspecific positions divided by the total number of GPS positions recorded during the entire tracking period for a particular individual. Habitat was determined by merging all filtered foraging GPS locations with high-resolution land cover information (SIOSE, Soil Information System of Spain, Junta de Andalucía; scale was 1:2500; last update 2011). Using this information, we calculated the proportional similarity index (PSi) following Schoener (1968). PSi is a measure of individual specialization based on habitatby-habitat deviations in an individual's habitat use relative to population level, average habitat use $(0=$ more specialized; $1=$ more generalist). PSi is based on the average pairwise overlap of the niche distribution of individuals and the population (Bolnick et al. 2002). Mean PSi among individuals was used to determine the average amount or prevalence of individual specialization in habitat use in the population (IS). We ran Monte Carlo permutations to test whether observed PSi values differed significantly from a random distribution of values subsampled from the population. We randomly reassigned habitat use for each yellow-legged gull in equal proportion to our observed data, and then calculated individual and population-level metrics for the random population. We generated random habitat use data for 10000 populations, thereby creating a null distribution of PSi values. We concluded that individuals were not sampling from a shared distribution of habitat use if our observed PSi values were $<95 \%$ of all randomly generated values (Araújo et al. 2007). 
All of these analyses were performed using the RInSp package (Zaccarelli et al. 2013) in the software package $\mathrm{R}$ ( $\mathrm{R}$ Core Team 2015). Pearson correlation tests indicated that no significant relationship exists between the number of GPS positions and the PSi values at the individual level $(\mathrm{p}=$ 0.71 ). We did not consider a sex effect because no significant differences in PSi values were found between sexes (ANOVA tests: $F_{1,17}=1.92, \mathrm{p}=0.19$ ).

In addition to the PSi values, we quantified the degree of individual spatial segregation within each habitat using Schoener's overlap index $D$-metric (Schoener 1968), indicating the relative use of particular microhabitats (Friedlaender et al. 2011). For this, we overlaid all filtered locations onto a grid of $100 \mathrm{~m}^{2}$ (corresponding to the minimum area used by the tracking gulls in the present study) to estimate the proportion of locations in any grid cell. The cell size was based on the minimum area encompassing a single habitat. $D$-metric values of 1 indicate a complete spatial overlap between 2 yellow-legged gulls in a pair, whereas values of 0 indicate complete spatial segregation. ANOVA and post hoc tests were applied to test differences in the $D$-metric index between individuals.

\section{RESULTS}

Based on the 28917 filtered locations recorded during 1 mo of the 2015 breeding season from the 18 tracked yellow-legged gulls, we detected the use of 11 different habitats (Table 1, Figs. 1 \& 2). At the population level, the relative use of each habitat (percentage of total locations) ranged from $28.4 \%$ for fishing ports and estuaries $(22.3 \%)$ to $\sim 1.0 \%$ for garbage dumps, agricultural lands and fish farms (Fig. 2).

\section{Individual specialization in habitat use}

At the individual level, we found PSi values ranging from 0.37 to 0.78 , with specialized individuals (low PSi values) mainly exploiting habitats such as fish farms, sea or estuarine areas, and less special- ized individuals (high PSi values) using a higher diversity of habitats (Fig. 2). Monte Carlo analyses of individual-versus-population niche variation indicated that specialized individuals were significantly prevalent within the population (IS $=0.52, \mathrm{p}<0.001$; Fig. 2).

\section{Individual spatial segregation within each habitat}

Based on $D$-metric values (spatial segregation between individuals within the same habitats), we found marked differences between habitats $\left(F_{10,1710}=\right.$ 136.69, $\mathrm{p}<0.001$; Fig. 3). Post hoc tests indicated that spatial overlap between individuals was significantly higher in garbage dumps $(D$-metric $=0.78 \pm 0.06)$, followed by water ponds, fish farms and fishing ports ( $D$-metric ranging from 0.36 to 0.41$)$, and estuaries $(D$-metric $=0.24 \pm 0.15)$. The lowest spatial overlap values were found for urban, wetland, saltpans, beach, sea and agricultural areas ( $D$-metric ranging from 0 to 0.16) (Fig. 3).

\section{DISCUSSION}

We examined the spatial ecology of yellow-legged gulls to test the degree of individual specialization in their habitat use, by tracking 18 individuals simultaneously over 1 mo during the breeding period. Our results support the hypothesis about winning spe- 


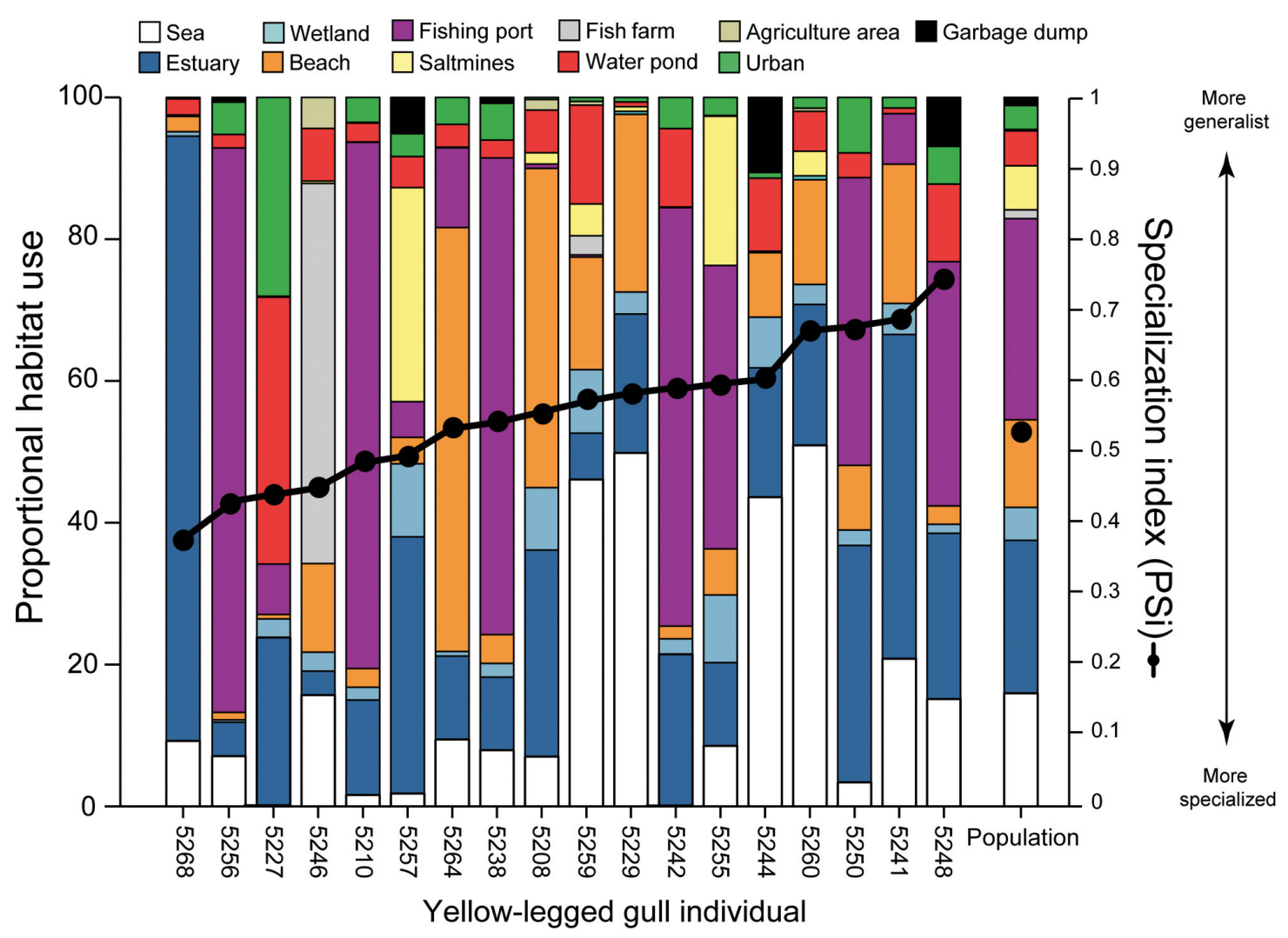

Fig. 2. Individual variation in habitat use between the 18 GPS-tracked yellow-legged gull Larus michahellis individuals during one month of the 2015 breeding season. Each individual ( $x$-axis) is represented by a vertical bar, subdivided by the proportion of locations in each habitat in relation to the total GPS locations and the specialization index PSi (black dots; $0=$ more specialized; $1=$ more generalist). Mean habitat use and the prevalence of individual specialization in habitat use in the population (IS; black dot in the population bar) are also represented (right bar)

cies, as they revealed a high diversity of habitats used by the yellow-legged gulls. Moreover, in accordance with ecological theory related to generalist species (Bolnick et al. 2003, Araújo et al. 2011), we also showed that variation within the population predominately derives from individual specialization in habitat use. Importantly, we found that the degree of spatial segregation between individuals differed markedly between habitats.

At the population level, yellow-legged gulls were able to use up to 11 main habitats present both in marine and terrestrial domains, including natural and human-made habitats. This high plasticity reflects the pronounced ability and behavioural flexibility of the yellow-legged gull to exploit a diverse suite of trophic resources, some of which are novel resources provided by humans, or use them for other activities such as resting, bathing or socializing. For example, it has been reported that in the marine environment or in fishing ports the yellow-legged gull exploits marine resources by foraging on natural prey in the open sea, or opportunistically forages on fishery discards (Duhem et al. 2003, Ramos et al. 2009). In the saltpans, estuaries and wetlands, birds exploit different resources such as fish, crustaceans and bivalves, predate on eggs and chicks of other birds, or use undisturbed areas to rest or socialize with conspecifics (Bosch 1996, Munilla 1997, Vidal et al. 1998, Buechley \& Șekercioğlu 2016). In beaches or urban areas, individuals scavenge on organic matter present in human waste or dead marine organisms, predate on urban vertebrates such as pigeons, or use the ponds present in the urban parks to bath or drink freshwater (Britton \& Morton 1994, Buechley \& Sekercioğlu 2016, Huig et al. 2016). In some specific habitats such as water ponds, in addition to preying on amphibians or freshwater fish, the gulls wash their feathers or rest (Sebastián-González et al. 2012). Most published studies indicate the high importance of trophic resources present in garbage dumps for the yellow-legged gull (Duhem et al. 2003, Ramos et al. 2009). Surprisingly, in our study, the importance of this habitat was very low. This result may be related to the low availability of urban dumps in the area 


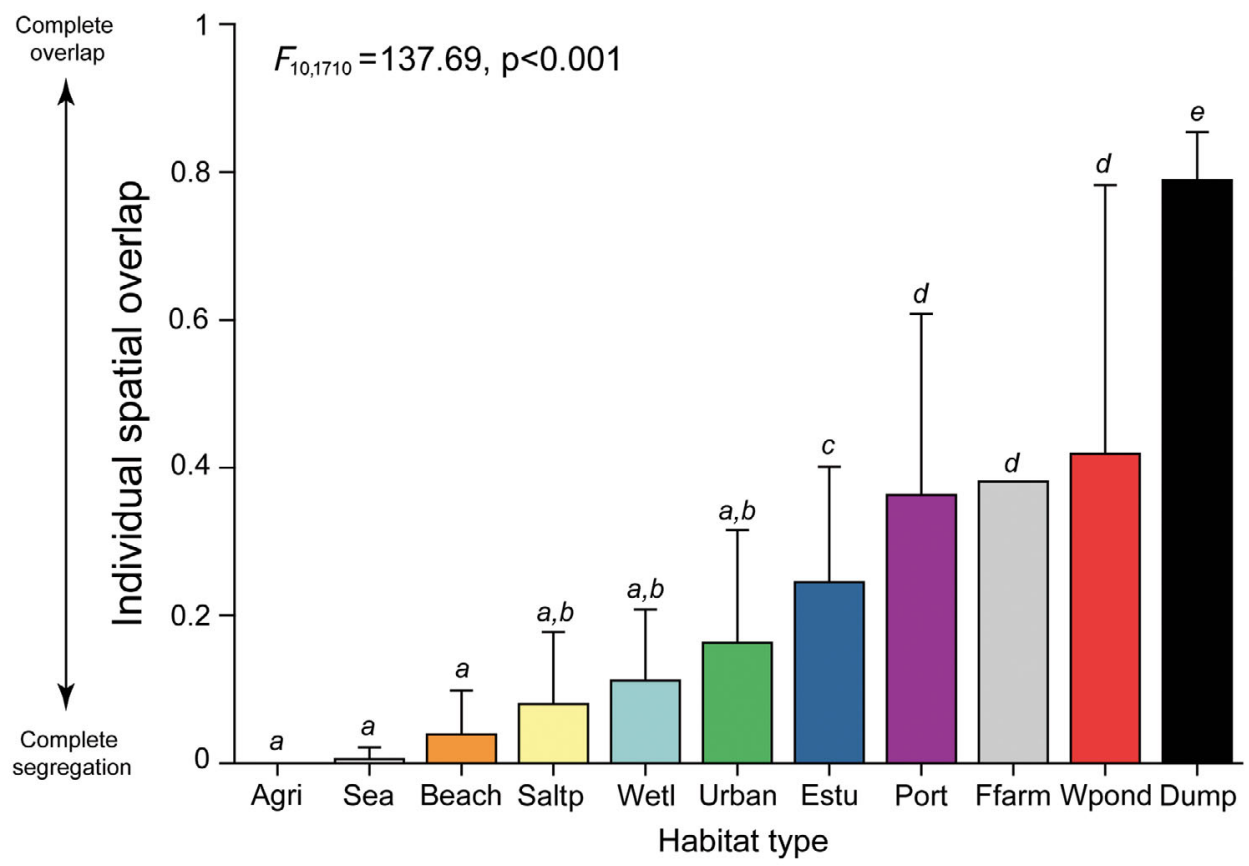

Fig. 3. Spatial overlap (mean and SD) between yellow-legged gull Larus michahellis individuals within each habitat $($ Agri $=$ agriculture area, Saltp = saltpans, Wetl $=$ wetlands, Estu $=$ estuaries, Port $=$ fishing ports, Ffarm $=$ fish farms, Wpond $=$ water ponds, Dump = garbage dumps $)$ based on Schoener's spatial overlap metric $(0=$ more segregation; $1=$ more overlap $)$. The results of post-hoc Tukey HSD tests are shown by the lowercase letters above each bar: for individual spatial overlap, the means of habitats with the same letter were not significantly different

covered by GPS-tracked individuals (Navarro et al. 2016).

Although all GPS-tracked yellow-legged gulls could potentially exploit all available habitats, based on PSi values - a metric to test individual specialization (Bolnick et al. 2002, Fodrie et al. 2015) we found clear differences in habitat use among individuals within the population. These results are coherent with the prediction that some generalist or opportunistic species are composed of ecologically heterogeneous individuals that repeatedly differ in behaviour and use of different subsets of available resources (Bolnick et al. 2002, Bearhop et al. 2004, Bell et al. 2009). Individual specialization is known to be widespread across a diverse set of taxa (Bolnick et al. 2003, Bell et al. 2009, Ceia \& Ramos 2015), including different seabird species and other marine predators (e.g. Vander Zanden et al. 2010, Votier et al. 2010, Masello et al. 2013, Ceia \& Ramos 2015, Tyson et al. 2015, Towner et al. 2016, Yurkowski et al. 2016). In general, individual specialization may have a strong impact on ecological processes and population dynamics, and there is evidence that this mechanism may reduce intra-specific competition among individuals, increase individual foraging efficiency and improve breeding success (Pierotti \& Annett 1991, Bolnick et al. 2003, Woo et al. 2008, Araújo et al. 2011). For this reason, the existence of individual specialization within populations of winning species could partially explain their success (Grémillet et al. 1999, Cardador et al. 2012, Chapple et al. 2012, Liebl \& Martin 2014, Ceia \& Ramos 2015, Potier et al. 2015). Specifically, individual specialization could help opportunistic species to exploit the wide range of ecological opportunities provided by human activities (food or shelter, among others) in heterogeneous landscapes, thereby becoming more competitive than losing species (Carrete et al. 2010, Cardador et al. 2011, Layman et al. 2015, Newsome et al. 2015, Robertson et al. 2015).

The high degree of specialization across yellowlegged gulls of southern Spain has management and conservation implications related to the implementation of effective actions to reduce specific impacts on human or conservation interests (Sanz-Aguilar et al. 2009, Bowen \& Lidgard 2013). For example, if the owners of fish farms wish to reduce the potential impact of yellow-legged gulls on their installations, one tractable management option is to remove gulls that specialize in this resource. One piece of clear evidence of the efficacy of such targeted measures is the reduction of the predation of the European storm petrel Hydrobates pelagicus by yellow-legged gulls, through the removal of specific petrel predators 
within the gull population (Sanz-Aguilar et al. 2009). However, it is important to point out that although these management measures could be efficient in the short term, other individuals can occupy the empty niche over longer periods.

Interestingly, we also found that the degree of spatial segregation between yellow-legged gulls differed between habitats. Based on the principle of competitive exclusion, competing individuals exploiting similar habitats are expected to segregate, especially when particular resources are limited (Gause 1973, Pianka 2000). Although we did not measure the availability of trophic resources or other types of resource related to other particular behaviours in each habitat, some of these observed differences may be explained by inter-habitat differences. For example, in garbage dumps or fish farms, high availability of resources and limited profitable surface area could allow some degree of spatial overlap between individuals exploiting similar trophic resources (CortésAvizanda et al. 2012, Arizaga et al. 2014). In contrast, in other habitats with prey resources for gulls, such as fishery discards at sea, individuals probably need to segregate in space to find food, or to reduce competition between conspecifics or with other bird species (Navarro et al. 2013, Patrick et al. 2014, Tyson et al. 2015). For this reason, the different degrees of individual spatial segregation between habitats may be viewed as a consequence of the distribution or availability of the resources used by gulls, or as a potential mechanism to reduce intra-specific competition (Bolnick et al. 2007, Matich et al. 2011, Robertson et al. 2015).

\section{CONCLUSIONS}

Our findings revealed that population-level generalism in habitat use in the yellow-legged gull arises through varying levels of individual specialization in habitat use and individual spatial segregation within each habitat, rather than all individuals being broad generalists. This combination of individual specialization and individual spatial segregation may reduce intra-specific competition, serving as 2 important mechanisms related to the success of these winning species in comparison to other, less successful species. Further multispecific investigations involving long-term GPS-tracking data covering the annual cycle of different colonies located in different environmental contexts would be useful to confirm that individual specialization in habitat use is a common phenomenon in winning and successful predators.
Acknowledgements. Thanks to the staff of the Biosphere Reserve of Marismas del Odiel, especially to Enrique Martínez, Laura Refojo and José Manuel Sayago. Also, thanks to everyone involved in the fieldwork: Rafa Silva, Manuel de la Riva, Carlos Gutiérrez-Expósito, Laura Gangoso, Juan Jesús Moreno, Joan Giménez, Alazne Díez and Antonio Palma. Sarah Young revised the English grammar. Laura Cardador provided very useful comments during the preparation of this paper. The work was supported by the ESFRI LifeWatch Project and Andalucía Talent Hub Program (European Union's Seventh Framework Program, Marie Skłodowska-Curie actions and Andalusian Knowledge Agency, Spain). UvA-BiTS bird tracking studies are facilitated by the UvA-BiTS virtual lab (www.UvA-BiTS.nl/ virtual-lab) built with support from the Netherlands eScience Center, SURFsara and SURF Foundation.

\section{LITERATURE CITED}

Alonso H, Almeida A, Granadeiro JP, Catry P (2015) Temporal and age-related dietary variations in a large population of yellow-legged gulls Larus michahellis: implications for management and conservation. Eur J Wildl Res 61:819-829

Araújo MS, Bolnick DI, Machado G, Giaretta AA, dos Reis SF (2007) Using $\delta^{13} \mathrm{C}$ stable isotopes to quantify individual-level diet variation. Oecologia 152:643-654

Araújo MS, Bolnick DI, Layman CA (2011) The ecological causes of individual specialisation. Ecol Lett 14:948-958

Arizaga J, Aldalur A, Herrero A, Cuadrado JF, Díez E, Crespo A (2014) Foraging distances of a resident yellowlegged gull (Larus michahellis) population in relation to refuse management on a local scale. Eur J Wildl Res 60: 171-175

* Bearhop S, Adams CE, Waldron S, Fuller RA, Macleod H (2004) Determining trophic niche width: a novel approach using stable isotope analysis. J Anim Ecol 73:1007-1012

*Bell AM, Hankison SJ, Laskowski KL (2009) The repeatability of behaviour: a meta-analysis. Anim Behav 77: 771-783

* Bolnick D, Yang L, Fordyce J, Davis J, Svanback R (2002) Measuring individual-level resource specialization. Ecology 83:2936-2941

*Bolnick DI, Svanbäck R, Fordyce JA, Yang LH, Davis JM, Hulsey CD, Forister ML (2003) The ecology of individuals: incidence and implications of individual specialization. Am Nat 161:1-28

Bolnick DI, Svanbäck R, Araújo MS, Persson L (2007) Comparative support for the niche variation hypothesis that more generalized populations also are more heterogeneous. Proc Natl Acad Sci USA 104:10075-10079

*Bosch M (1996) The effects of culling on attacks by yellowlegged gulls (Larus cachinnans) upon three species of herons. Colon Waterbirds 19:248-252

*B Bouten W, Baaij EW, Shamoun-Baranes J, Camphuysen KCJ (2013) A flexible GPS tracking system for studying bird behaviour at multiple scales. J Ornithol 154:571-580

*Bowen WD, Lidgard D (2013) Marine mammal culling programs: review of effects on predator and prey populations. Mammal Rev 43:207-220

Britton JC, Morton B (1994) Marine carrion and scavengers. Oceanogr Mar Biol Annu Rev 32:369-434

* Buechley ER, Şekercioğlu ÇH (2016) The avian scavenger crisis: looming extinctions, trophic cascades, and loss of 
critical ecosystem functions. Biol Conserv 198:220-228

Cardador L, Carrete M, Mañosa S (2011) Can intensive agricultural landscapes favour some raptor species? The marsh harrier in north-eastern Spain. Anim Conserv 14: 382-390

Cardador L, Carrete M, Mañosa S (2012) Inter-individual variability and conspecific densities: consequences for population regulation and range expansion. PLOS ONE $7: \mathrm{e} 33375$

Carrete M, Lambertucci SA, Speziale K, Ceballos O and others (2010) Winners and losers in human-made habitats: interspecific competition outcomes in two neotropical vultures. Anim Conserv 13:390-398

Ceia FR, Ramos JA (2015) Individual specialization in the foraging and feeding strategies of seabirds: a review. Mar Biol 162:1923-1938

Ceia F, Paiva V, Fidalgo V, Morais L and others (2014) Annual and seasonal consistency in the feeding ecology of an opportunistic species, the yellow-legged gull Larus michahellis. Mar Ecol Prog Ser 497:273-284

Chapple DG, Simmonds SM, Wong BBM (2012) Can behavioral and personality traits influence the success of unintentional species introductions? Trends Ecol Evol 27: $57-64$

Clavel J, Julliard R, Devictor V (2011) Worldwide decline of specialist species: toward a global functional homogenization? Front Ecol Environ 9:222-228

* Cortés-Avizanda A, Jovani R, Carrete M, Donázar JA (2012) Resource unpredictability promotes species diversity and coexistence in an avian scavenger guild: a field experiment. Ecology 93:2570-2579

№ll SRX, Bell AM, Bolnick DI, Ratnieks FLW (2012) An evolutionary ecology of individual differences. Ecol Lett 15: 1189-1198

Duhem C, Vidal E, Legrand J, Tatoni T (2003) Opportunistic feeding responses of the yellow-legged gull Larus michahellis to accessibility of refuse dumps. Bird Study 50:61-67

Fodrie FJ, Yeager LA, Grabowski JH, Layman CA, Sherwood GD, Kenworthy MD (2015) Measuring individuality in habitat use across complex landscapes: approaches, constraints, and implications for assessing resource specialization. Oecologia 178:75-87

Friedlaender AS, Johnston DW, Fraser WR, Burns J, Patrick NH, Costa DP (2011) Ecological niche modeling of sympatric krill predators around Marguerite Bay, western Antarctic Peninsula. Deep Sea Res II 58:1729-1740

Gause GF (1973) The struggle for existence. Williams and Wilkins, Baltimore, MD

KGrémillet D, Wilson RP, Storch S, Gary Y (1999) Threedimensional space utilization by a marine predator. Mar Ecol Prog Ser 183:263-273

Huig N, Buijs RJ, Kleyheeg E (2016) Summer in the city: behaviour of large gulls visiting an urban area during the breeding season. Bird Study 63:214-222

Layman CA, Newsome SD, Gancos Crawford T (2015) Individual-level niche specialization within populations: emerging areas of study. Oecologia 178:1-4

Liebl AL, Martin LB (2014) Living on the edge: range edge birds consume novel foods sooner than established ones. Behav Ecol 25:1089-1096

Martínez-Abraín A, Jiménez J (2016) Anthropogenic areas as incidental substitutes for original habitat. Conserv Biol 30:593-598

Masello JF, Wikelski M, Voigt CC, Quillfeldt P (2013) Distri- bution patterns predict individual specialization in the diet of dolphin gulls. PLOS ONE 8:e67714

*Matich P, Heithaus MR, Layman CA (2011) Contrasting patterns of individual specialization and trophic coupling in two marine apex predators. J Anim Ecol 80:294-305

McKinney ML (2006) Urbanization as a major cause of biotic homogenization. Biol Conserv 127:247-260

McKinney ML, Lockwood JL (1999) Biotic homogenization: a few winners replacing many losers in the next mass extinction. Trends Ecol Evol 14:450-453

Munilla I (1997) Henslow's swimming crab (Polybius henslowii) as an important food for yellow-legged gulls (Larus cachinnans) in NW Spain. ICES J Mar Sci 54:631-634

Navarro J, Votier SC, Aguzzi J, Chiesa JJ, Forero MG, Phillips RA (2013) Ecological segregation in space, time and trophic niche of sympatric planktivorous petrels. PLOS ONE 8:e62897

Navarro J, Grémillet D, Afán I, Ramírez F, Bouten W, Forero MG (2016) Feathered detectives: real-time GPS tracking of scavenging gulls pinpoints illegal waste dumping. PLOS ONE 11:e0159974

* Newsome SD, Garbe HM, Wilson EC, Gehrt SD (2015) Individual variation in anthropogenic resource use in an urban carnivore. Oecologia 178:115-128

Olden JD, Poff NL, Douglas MR, Douglas ME, Fausch KD (2004) Ecological and evolutionary consequences of biotic homogenization. Trends Ecol Evol 19:18-24

* Osterback AMK, Frechette DM, Hayes SA, Shaffer SA, Moore JW (2015) Long-term shifts in anthropogenic subsidies to gulls and implications for an imperiled fish. Biol Conserv 191:606-613

*Passos C, Navarro J, Giudici A, González-Solís J (2010) Effects of extra mass on the pelagic behavior of a seabird. Auk 127:100-107

*Patrick SC, Bearhop S, Grémillet D, Lescroël A and others (2014) Individual differences in searching behaviour and spatial foraging consistency in a central place marine predator. Oikos 123:33-40

* Payo-Payo A, Oro D, Igual JM, Jover L, Sanpera C, Tavecchia G (2015) Population control of an overabundant species achieved through consecutive anthropogenic perturbations. Ecol Appl 25:2228-2239

* Phillips RA, Xavier JC, Croxall JP (2003) Effects of satellite transmitters on albatrosses and petrels. Auk 120: 1082-1090

Pianka ER (2000) Evolutionary ecology. Addison Wesley, San Francisco, CA

* Pierotti R, Annett CA (1991) Diet choice in the herring gull: constraints imposed by reproductive and ecological factors. Ecology 72:319-328

* Potier S, Carpentier A, Grémillet D, Leroy B, Lescroël A (2015) Individual repeatability of foraging behaviour in a marine predator, the great cormorant, Phalacrocorax carbo. Anim Behav 103:83-90

R Core Team (2015) R: a language and environment for statistical computing. Vienna. www.R-project.org/

* Ramírez F, Navarro J, Afán I, Hobson KA, Delgado A, Forero MG (2012) Adapting to a changing world: unraveling the role of man-made habitats as alternative feeding areas for slender-billed gull (Chroicocephalus genei). PLOS ONE 7:e47551

Ramos R, Ramírez F, Sanpera C, Jover L, Ruiz X (2009) Diet of yellow-legged gull (Larus michahellis) chicks along the Spanish western Mediterranean coast: the relevance of refuse dumps. J Ornithol 150:265-272 
Ramos R, Ramírez F, Carrasco JL, Jover L (2011) Insights into the spatiotemporal component of feeding ecology: an isotopic approach for conservation management sciences. Divers Distrib 17:338-349

Robertson A, McDonald RA, Delahay RJ, Kelly SD, Bearhop S (2015) Resource availability affects individual niche variation and its consequences in group-living European badgers Meles meles. Oecologia 178:31-43

Rock P, Camphuysen CJ, Shamoun-Baranes J, Ross-Smith VH, Vaughan IP (2016) Results from the first GPS tracking of roof-nesting herring gulls Larus argentatus in the UK. Ring Migr 31:47-62

Sanz-Aguilar A, Martínez-Abraín A, Tavecchia G, Mínguez E, Oro D (2009) Evidence-based culling of a facultative predator: efficacy and efficiency components. Biol Conserv 142:424-431

Schoener TW (1968) The Anolis lizards of Bimini: resource partitioning in a complex fauna. Ecology 49:704-726

Sebastián-González E, Navarro J, Sánchez-Zapata JA, Botella F, Delgado A (2012) Water quality and avian inputs as sources of isotopic variability in aquatic macrophytes and macroinvertebrates. J Limnol 71:191-199

Shultz S, Bradbury RB, Evans KL, Gregory RD, Blackburn TM (2005) Brain size and resource specialization predict long-term population trends in British birds. Proc Biol Sci 272:2305-2311

Sih A, Ferrari MCO, Harris DJ (2011) Evolution and behavioural responses to human-induced rapid environmental change. Evol Appl 4:367-387

Skórka P, Martyka R, Wójcik JD, Lenda M (2014) An invasive gull displaces native waterbirds to breeding habitats more exposed to native predators. Popul Ecol 56:359-374

Thaxter CB, Ross-Smith VH, Clark JA, Clark NA and others (2014) A trial of three harness attachment methods and their suitability for long-term use on lesser black-backed gulls and great skuas. Ring Migr 29:65-76

Thaxter CN, Ross-Smith VH, Clark JA, Clark NA and others (2016) Contrasting effects of GPS device and harness attachment on adult survival of lesser black-backed gulls Larus fuscus and great skuas Stercorarius skua. Ibis 158: 279-290

Editorial responsibility: Rory Wilson, Swansea, UK
Tinker MT, Costa DP, Estes JA, Wieringa N (2007) Individual dietary specialization and dive behaviour in the California sea otter: using archival time-depth data to detect alternative foraging strategies. Deep Sea Res II 54: 330-342

Towner AV, Leos-Barajas V, Langrock R, Schick RS and others (2016) Sex-specific and individual preferences for hunting strategies in white sharks. Funct Ecol 30: 1397-1407

*Tyson C, Shamoun-Baranes J, Van Loon EE, Camphuysen K, Hintzen NT (2015) Individual specialization on fishery discards by lesser black-backed gulls (Larus fuscus). ICES J Mar Sci 72:1882-1891

*Vander Zanden HB, Bjorndal KA, Reich KJ, Bolten AB (2010) Individual specialists in a generalist population: results from a long-term stable isotope series. Biol Lett 6: 711-714

Vidal E, Medail F, Tatoni T (1998) Is the yellow-legged gull a superabundant bird species in the Mediterranean? Impact on fauna and flora, conservation measures and research priorities. Biodivers Conserv 7:1013-1026

* Votier SC, Bearhop S, Witt MJ, Inger R, Thompson D, Newton J (2010) Individual responses of seabirds to commercial fisheries revealed using GPS tracking, stable isotopes and vessel monitoring systems. J Appl Ecol 47: 487-497

*Woo KJ, Elliott KH, Davidson M, Gaston AJ, Davoren GK (2008) Individual specialization in diet by a generalist marine predator reflects specialization in foraging behaviour. J Anim Ecol 77:1082-1091

*Worm B, Barbier EB, Beaumont N, Duffy JE and others (2006) Impacts of biodiversity loss on ocean ecosystem services. Science 314:787-790

Kurkowski DJ, Ferguson S, Choy ES, Loseto LL and others (2016) Latitudinal variation in ecological opportunity and intraspecific competition indicates differences in niche variability and diet specialization of Arctic marine predators. Ecol Evol 6:1666-1678

* Zaccarelli N, Bolnick DI, Mancinelli G (2013) RInSp: an R package for the analysis of individual specialization in resource use. Methods Ecol Evol 4:1018-1023

Submitted: January 17, 2017; Accepted: March 16, 2017

Proofs received from author(s): April 11, 2017 